\title{
Loyola University New Orleans College of Law: A History
}

\author{
Kaitlyn Hall*
}

* Department of Educational Leadership and Policies, University of South Carolina, Columbia, South Carolina

E-mail:kh88@email.sc.edu

\section{Article Info}

Received: January 9, 2022

Revised: February 12, 2022

Accepted: February 15, 2022

$10.46303 /$ jcsr.2022.7

\section{How to cite}

Hall, K. (2022). Loyola University New Orleans College of Law: A History. Journal of Curriculum Studies Research, 4(1), 76-78. https://doi.org/10.46303/jcsr.2022.7

\section{Copyright license}

This is an Open Access article distributed under the terms of the Creative Commons Attribution 4.0 International license.

\section{ABSTRACT}

Maria Isabel Medina brings to life the story of Loyola University's law school, unique in its mission to bring the law profession to members of the working class while maintaining its identity as the only Jesuit law school in the U.S. South. Founded in 1914, the law school faced various obstacles early in its formative years, including the laborious path to accreditation in the legal profession. Loyola University New Orleans College of Law: A History details the myriad ways that the law school was impacted by state, national, and global circumstances such as the 1918 Influenza pandemic, World Wars I and II, the Civil Rights Movement, and the devastation wrought by Hurricane Katrina. Indeed, Medina illustrates the arduous journey that the school undertook to voluntarily desegregate at a time when much of Louisiana and the U.S. South upheld segregation. Likewise, Loyola University New Orleans College of Law: A History provides valuable insight into the challenging climate that women faced at the law school and in the legal profession. In Loyola University College of Law: A History, Medina illuminates the significance of the law school's role in the field of legal education and New Orleans and Louisiana history.

\section{KEYWORDS}

Loyola University College of Law: A History (book); Maria Isabel Medina; nonfiction; higher education; religion; Louisiana. 


\section{BOOK REVIEW}

In Loyola University New Orleans College of Law: A History, Maria Isabel Medina brings to life the institutional history of the university's law school. Yet, from its beginnings in 1914, Loyola's law school had unique qualities that other law schools did not: the only law school in the U.S. South that was characterized by a Jesuit Catholic philosophy and an affirmed commitment to social justice. Operating at night, the law school provided access to the legal profession to the working class at a time when it was accessible largely to the wealthy. Judges and other legal professionals taught classes at the law school on a volunteer, part-time basis. Additionally, Loyola's law school offered legal assistance to the poor and was the first law school in Louisiana to desegregate.

Although Father Alphonse Otis, S.J., Loyola University's President in 1914, emphasized that the law school was non-sectarian, he also proclaimed the role of religion within the school. "God will not be debarred from our professional schools, and religion will be our guiding star... God's holy Commandments will be esteemed and reverenced, and our young men will be taught a code of ethics which will acknowledge God's rights and supreme dominion over man" (p. 26). In later years, however, Loyola University struggled to find a balance between serving the needs of its primarily working, part-time students and maintaining professional standards as the legal profession evolved into an academic discipline. As Loyola University sought to elevate its national reputation, including accreditation of its law school, the centrality of religion in the school's operations became an unyielding obstacle.

While curricula decisions were made by the dean of the law school, these decisions were still influenced by the university through the office of the regent, in which Jesuit philosophy continued to play a significant role in the operation of the law school. As a result, accreditation bodies such as the American Bar Association and Association of American Law Schools maintained that part of the law school's failure to gain membership came from the Jesuit influence over the school. Membership to both entities was awarded once the law school enacted required changes that ensured that the dean, rather than the regent, exercised active control of the law school. Even after being awarded accreditation, however, the institution's Board of Trustees still had some control in curricula and faculty decisions of the law school. Thus, in illustrating this battle of institutional mission versus professional standards, Medina shows the complexity of religion in this non-sectarian law school at a Jesuit institution.

As with other law schools in Louisiana and the U.S. South, Loyola University's College of Law was among the first professional programs to desegregate. As Louisiana had no mandate regarding desegregation at educational institutions, Loyola University endured a hard-fought journey to integration, especially as other law schools at institutions at Tulane University and Louisiana State University resisted desegregation efforts. While some of the law school's faculty, students, and alumni supported and were instrumental in desegregation in Louisiana history, these efforts were not unanimously supported at the law school. What is unique about Loyola University's journey is the role of religion in the fight for desegregation at the university. While 
the university's Board of Trustees decided to not admit Black students for much of the 1940s, faculty members of the university and the law school led a sub-committee under the Catholic Committee of the South with a focus on "eliminating 'prejudice, intolerance, segregation, jimcrowism and kindred evils from within the framework of Catholic life in New Orleans'" (p. 71). Yet, the work of this committee did not bear immediate fruit. It would be a few years later when the law school would finally desegregate in 1951, even after Reverend Louis Twomey, S.J., wrote to the Society of Jesus in Rome for guidance as his recommendation for integration had largely been ignored.

Through this institutional history, composed of primary and secondary sources, Medina also provides insight into other events that are often overlooked in the course of history until recent years. For instance, she shows how the law school, the New Orleans area in general, were affected by "plague" and illnesses such as yellow fever, smallpox, and cholera. Likewise, the role that World War I and the 1918 Influenza Pandemic played on the decline of student enrollment is briefly mentioned. More on the ways that the pandemic affected the law school,, would be welcome.

Similarly, the history of Loyola University's College of Law also illustrates how it, and the university in general, have weathered hurricanes that have made landfall in the area. After all, New Orleans, susceptible to such unpredictable forces of nature, has an extensive hurricane history. Therefore, the inclusion of Loyola University's law school operating by candlelight, from a lack of electricity, following the 1915 hurricane of New Orleans is refreshing, although brief. Additionally, the author illustrates the myriad ways that Hurricane Katrina affected the operations and community of the College of Law in 2005. Loyola University College of Law is unique in that it is one of few law schools that are geographically situated in areas susceptible to hurricanes. While Medina describes in detail the displacement of the law school community, more details on other ways students were affected and the relationship between the law school and the New Orleans area in the aftermath of Katrina would provide further insight into the full extent that Hurricane Katrina affected faculty and students, the town and gown relations between the college and city, and any role that religion may have played during and after the storm. However, Medina provides a unique context that is missing from other law schools as the relationship between hurricanes and higher education is a perspective limited in the history of legal education.

\section{REFERENCES}

Medina, M. I. (2016). Loyola University New Orleans College of Law: A history. Louisiana State University Press. 